\title{
Slow Kinetics of Miniature IPSCs during Early Postnatal Development in Granule Cells of the Dentate Gyrus
}

\author{
Greg S. Hollrigel and Ivan Soltesz \\ Department of Anatomy and Neurobiology, University of California, Irvine, California 92697
}

\begin{abstract}
Whole-cell patch-clamp recordings were used to investigate the properties of $\mathrm{GABA}_{\mathrm{A}}$ receptor-mediated postsynaptic currents during development in dentate gyrus granule cells from neonatal [postnatal day $0(\mathrm{PO})]$ to adult rats in brain slices. The frequency of miniature IPSCs (mIPSCs) was low at birth and increased progressively with age. The mIPSCs of all ages could be satisfactorily fitted with the sum of a single exponential rise and single exponential decay. From P0 to P14, both the rise time and the decay time constants were significantly longer than in the adult. The mIPSC rise and decay kinetics did not change during the first 2 postnatal weeks, but during the third week the kinetics sped up and by P21 attained adult values. In contrast, the amplitude of the mIPSCs did not change during development. The synaptic $\mathrm{GABA}_{\mathrm{A}}$ receptors in immature and
\end{abstract}

adult cells showed differential sensitivity to modulators. The subunit-specific benzodiazepine agonist zolpidem increased the decay time constant of the IPSCs of immature granule cells with a reduced potency compared with the adult. Furthermore, zinc decreased the amplitude and decay time constant of mIPSCs from developing granule cells, whereas it had no effect on mIPSCs in adult neurons.

The results reveal for the first time that until the end of the second postnatal week the synaptic $\mathrm{GABA}_{\mathrm{A}}$ receptor-mediated currents in dentate granule cells display slower rise and decay kinetics but similar amplitudes compared with adult, resulting in a net decrease in synaptic charge transfer during development.

Key words: $G A B A_{A}$ receptor; development; dentate gyrus; inhibition; subunit; zolpidem; zinc
The GABAergic innervation of dentate granule cells plays a central role in regulating the information flow between the entorhinal cortex and the hippocampus (Buzsáki et al., 1983). At least five types of GABAergic neurons supply inhibitory terminals to adult dentate granule cells, specifically innervating spatially segregated parts of the neuron such as the axon initial segment, soma, and proximal and distal dendrites (Halasy and Somogyi, 1993; Han et al., 1993). The high specificity of target selection by dentate interneurons has important functional consequences (Cobb et al., 1995; Soltesz et al., 1995; Miles et al., 1996). Although there has been a considerable increase in our understanding of the operational principles of inhibitory microcircuits in the adult (Freund and Buzsáki, 1996), little is known about the synaptic construction of the dentate inhibitory system during development.

There are several clues which indicate that the organization of the developing dentate gyrus is fundamentally different from the adult. First, dentate GABAergic cells are born prenatally, whereas $80 \%$ of the granule cells are generated after birth (Schlessinger et al., 1975, 1978; Bayer, 1980; Soriano et al., 1989). Second, early in life, most GABAergic functions take place via $\mathrm{GABA}_{\mathrm{A}}$ receptors, because postsynaptic $\mathrm{GABA}_{\mathrm{B}}$ responses develop relatively late (Fukuda et al., 1993, Gaiarsa et al., 1995). Third, in contrast to the adult hippocampus, in which major roles for GABA are the control of excitability, the generation of $40 \mathrm{~Hz}$ oscillations, and the precision timing of action potentials (Buzsáki et al., 1983; Soltesz and Deschênes,

Received Jan. 16, 1997; revised March 11, 1997; accepted April 17, 1997.

This work was supported by March of Dimes Basil O'Connor Research Scholar Award (5-FY95-1143) and the American Epilepsy Society (EFA-21311) to I.S. We thank Ms. G. Sandor for expert technical assistance, Dr. J. Dempster for providing the Strathclyde Electrophysiology Software, and Dr. Y. De Koninck for the Synapse software.

Correspondence should be addressed to Dr. Ivan Soltesz, Department of Anatomy and Neurobiology, University of California, Irvine, CA 92697-1280.

Copyright (C) 1997 Society for Neuroscience $0270-6474 / 97 / 175119-10 \$ 05.00 / 0$
1993; Whittington et al., 1995), in immature neurons GABA has several developmental roles. For example, GABA influences the outgrowth of neuronal processes in picomolar concentrations (Behar et al., 1996), modulates DNA synthesis (LoTurco et al., 1995), and regulates neuronal phenotype (Marty et al., 1996). These developmental actions of GABA are likely to be associated with the fact that $\mathrm{GABA}_{\mathrm{A}}$ activation early in life leads to depolarizations and the opening of voltage-gated $\mathrm{Ca}^{2+}$ channels, resulting in various developmental changes via increases in intracellular $\left[\mathrm{Ca}^{2+}\right]$ (Ben-Ari et al., 1989; Cherubini et al., 1991; Yuste and Katz, 1991; Gaiarsa et al.,

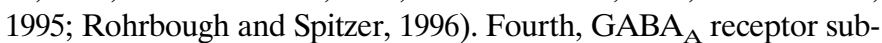
unit expression undergoes a prominent switch during postnatal development (Laurie et al., 1992; Fritschy et al., 1994). The functional consequences of the developmental changes in the subunit composition of $\mathrm{GABA}_{\mathrm{A}}$ receptors in cortical structures are not well understood.

This study has been undertaken to answer the following questions. (1) Can spontaneous GABA $_{\mathrm{A}}$ IPSCs be revealed in immature dentate granule cells? (2) If yes, given the pivotal importance of the amplitude and kinetics of the synaptic events in regulating the timing of neuronal signals, what differences do the GABAergic events show in immature and adult granule cells? (3) Do granule cells at different maturational stages display distinct $\mathrm{GABA}_{\mathrm{A}}$ receptor-mediated responses? (4) Do synaptic $\mathrm{GABA}_{\mathrm{A}}$ receptors respond differently to subunit-specific modulators in the developing versus adult dentate gyrus? The answers to these questions are important because they advance our knowledge of how $\mathrm{GABA}_{\mathrm{A}}$ signals operate in the developing cortico-limbic system.

\section{MATERIALS AND METHODS}

Slice preparation. Brain slices were prepared similar to what has been described previously (Otis and Mody, 1992; Staley et al., 1992). Neonatal Wistar rats $(\mathrm{P} 0-\mathrm{P} 5)$ were anesthetized by hypothermia, $\mathrm{P} 6-\mathrm{P} 14$ rats were anesthetized with halothane, and older rats (P21-adult) were anesthe- 
tized with sodium pentobarbital $(75 \mathrm{mg} / \mathrm{kg}$, i.p.). Anesthetized rats were decapitated, and the brains were removed and cooled in $4{ }^{\circ} \mathrm{C}$ oxygenated $\left(95 \% \mathrm{O}_{2} / 5 \% \mathrm{CO}_{2}\right)$ artificial cerebral spinal fluid (ACSF) composed of (in mM): $126 \mathrm{NaCl}, 2.5 \mathrm{KCl}, 26 \mathrm{NaHCO}_{3}, 2 \mathrm{CaCl}_{2}, 2 \mathrm{MgCl}_{2}, 1.25$ $\mathrm{NaH}_{2} \mathrm{PO}_{4}$, and 10 glucose. Horizontal brain slices (Staley et al., 1992) $(450 \mu \mathrm{m})$ were prepared with a vibratome tissue sectioner (Lancer Series 1000). The brain slices were sagittally bisected into two hemispheric components and incubated submerged in $32^{\circ} \mathrm{C}$ ACSF for $1 \mathrm{hr}$.

Electrophysiology. Individual slices were transferred to a submersiontype recording chamber (Soltesz et al., 1995; Hollrigel et al., 1996) perfused with ACSF containing $10 \mu \mathrm{M}$ 2-amino-5-phosphovaleric acid (APV) and $5 \mu \mathrm{M}$ 6-cyano-7-nitroquinoxaline-2,3-dione (CNQX); in some experiments, the perfusion solution included $1 \mu \mathrm{M}$ tetrodotoxin (TTX). The brain slices rested on filter paper and were stabilized with platinum wire weights. The tissue was superfused continuously with humidified $95 \% \mathrm{O}_{2} / 5 \% \mathrm{CO}_{2}$, and the temperature of the perfusion solution was maintained at $36^{\circ} \mathrm{C}$. All salts were obtained from Fluka (Buchs, Switzerland). APV and CNQX were purchased from Tocris, and TTX was obtained from Calbiochem (LaJolla, CA). Drugs were applied via the perfusion system. Zolpidem (10 mM stock; courtesy of Dr. G. White, Neurogen Corp.) and zinc solutions were prepared daily.

Patch pipettes were pulled from borosilicate (KG-33) glass capillary tubing (1.5 mm outer diameter; Garner Glass) with a Narishige PP-83 two-stage electrode puller. Pipette solutions consisted of (in mM): 140 $\mathrm{CsCl}, 2 \mathrm{MgCl}_{2}$, and $10 \mathrm{HEPES}$, and in some experiments, 3 QX-314, 0.2 EGTA, and/or biocytin (0.3\%). "Blind" whole cell recordings were obtained as described previously (Blanton et al., 1989; Staley et al., 1992). Recordings were obtained with an Axopatch-200A amplifier (Axon Instruments, Foster City, CA) and digitized at $88 \mathrm{kHz}$ (Neurocorder, NeuroData) before being stored in pulse code modulation form on videotape. The series resistance was monitored throughout the recordings, and the data were rejected if it increased beyond $15 \mathrm{M} \Omega$.

Analysis. Recordings were filtered at $3 \mathrm{kHz}$ before digitization at 20 $\mathrm{kHz}$ by a personal computer for analysis using Strathclyde Electrophysiology Software (courtesy of Dr. J. Dempster) and Synapse software (courtesy of Dr. Y. De Koninck). Detection of individual IPSCs was performed with a software trigger described previously (Otis and Mody, 1992; Soltesz et al., 1995). All of the detected events were analyzed, and any noise that spuriously met trigger specifications was rejected. A least-squares Simplex-based algorithm was used to fit the ensemble average with the sum of two (one rising and one decaying) or three (one rising and two decaying) exponentials:

$$
I(t)=-A^{*} e^{-\tau_{\mathrm{r}} / t}+A_{1}{ }^{*} e^{-\tau_{\mathrm{D} 1} / t}+A_{2}{ }^{*} e^{-\tau_{\mathrm{D} 2} / t}
$$

where $I(t)$ is the mIPSC as a function of time $(t) ; A_{1}+A_{2}=A$ are constants; and $\tau_{\mathrm{r}}, \tau_{\mathrm{D} 1}$, and $\tau_{\mathrm{D} 2}$ are the rise, fast decay, and slow decay time constants, respectively. For single exponential decays, $A_{1}$ was equal to 0. As described before (Soltesz and Mody, 1995; Hollrigel et al., 1996), to evaluate the improvement of the fit by adding a second exponential decay component, an F-test was used to assess the improvement in the value of the ratio $\left(S S E_{1}-S S E_{2}\right) / S S E_{2}$ ("\%SSE improvement"), where $S S E_{1}$ and $S S E_{2}$ are the sum of squared errors of the fits with one or two exponential decays, respectively. When the \%SSE improvement is not significant (as is the case in granule cells of all ages; see below), it indicates that the mIPSC from such a cell is described satisfactorily by the use of a single exponential rise and a single exponential decay function, and the $\tau_{\mathrm{r}}$ and the $\tau_{\mathrm{D} 2}$ from this fit can be used (by contrast, when the $\%$ SSE improvement is significant, e.g., after dendrotomy performed in control medium, the $\tau_{\mathrm{r}}, \tau_{\mathrm{D} 1}$, and $\tau_{\mathrm{D} 2}$ are all considered in the subsequent analysis) (Soltesz and Mody, 1995). Statistical analyses were performed with SPSS for Windows or SigmaPlot, with a level of significance of $p \leq$ 0.05 . Data are presented as mean \pm SE ( $n$ is number of cells).

Histology. To visualize recorded cells filled with biocytin, slices were processed as whole mounts (Claiborne et al., 1986). Briefly, after allowing diffusion of the tracer for $20-60 \mathrm{~min}$ in the recording chamber, the slice was fixed in a solution of $4 \%$ paraformaldehyde, $2.5 \%$ glutaraldehyde, and $0.2 \%$ picric acid overnight at $4{ }^{\circ} \mathrm{C}$. The sections were washed thoroughly in $0.1 \mathrm{~m}$ phosphate buffer (PB) and subsequently cryoprotected in $10 \%$ and $20 \%$ sucrose. The tissue was then frozen in liquid nitrogen and thawed. Slices were incubated in $1 \% \mathrm{H}_{2} \mathrm{O}_{2}$ for $30 \mathrm{~min}$ and washed extensively. The tissue was incubated in an ABC solution (Vector, Burlingame, CA) overnight at $4^{\circ} \mathrm{C}$ and washed thoroughly before it was reacted with $3,3^{\prime}$-diaminobenzidine tetrahydrochloride (concentration, $0.015 \%$ ) and $0.006 \% \mathrm{H}_{2} \mathrm{O}_{2}$. The reacted slices were cleared in an ascend- ing series of glycerol (Claiborne et al., 1986) and coverslipped before the cells were reconstructed with a camera lucida.

\section{RESULTS}

$\mathrm{GABA}_{\mathrm{A}}$ receptor-mediated miniature events are present at all postnatal ages and their frequency increases during development in granule cells of the dentate gyrus

GABA-mediated postsynaptic currents were recorded from dentate granule cells voltage-clamped at $-60 \mathrm{mV}$ with $\mathrm{Cl}^{-}$-filled pipettes $\left(\left[\mathrm{Cl}^{-}\right]_{\text {in }}=\left[\mathrm{Cl}^{-}\right]_{\text {out }}\right)$ (Otis and Mody, 1992) (throughout the experiments reported in this paper, to standardize our recording site, we restricted our recordings to the dorsal blade and the adjacent half of the crest of the granule cell layer). The inward currents (Fig. 1) reversed at $-0.5 \pm 2.1 \mathrm{mV}$ (predicted $E_{\mathrm{Cl}}=$ $0 \mathrm{mV}$ ) and were reversibly blocked by the $\mathrm{GABA}_{\mathrm{A}}$ receptor antagonist bicuculline ( $20 \mu \mathrm{M} ; n=3$; data not shown) (the developmental changes in the relationship between $E_{\mathrm{Cl}}$ and the resting membrane potential, input resistance, and neuronal rhythms will be examined in a separate study). In the presence of APV, CNQX, and TTX, mIPSCs were detected in $86.0 \%$ (49/57) of the cells from $\mathrm{P} 0-\mathrm{P} 4$ rats. The frequency of the mIPSCs increased with age (Fig. 1) from $0.8 \pm 0.2 \mathrm{~Hz}(\mathrm{P} 0-\mathrm{P} 4 ; n=13)$ to the adult value of $11.0 \pm 2.1 \mathrm{~Hz}(n=6)$. The low proportion of cells without miniature synaptic events from $\mathrm{P} 0-\mathrm{P} 4$ rats suggests that most granule cells receive GABAergic synaptic innervation shortly after becoming postmitotic, presumably from interneurons already present in the dentate network at birth (Amaral and Kurz, 1985; Lubbers et al., 1985; Dupuy and Houser, 1996). The developmental increase in the frequency of miniature events most likely reflects an increase in the number of GABAergic synaptic release sites related to the increased innervation of granule cells by axons of interneurons (Lubbers and Frotscher, 1988; Seress et al., 1989; Seress and Ribak, 1990; Dupuy and Houser, 1996). In contrast to cerebellar granule cells (Tia et al., 1996), bicuculline did not decrease the baseline "noise," indicating that there is no significant activation of $\mathrm{GABA}_{\mathrm{A}}$ receptors by ambient GABA. In addition, there was no significant increase in the baseline "noise" during development (e.g., Fig. 1), in contrast to what has been observed in cerebellar granule cells (Tia et al., 1996).

\section{mIPSCs in immature cells display slower kinetics but similar amplitudes compared with adult}

Figure $2 A$ is an example of averaged mIPSCs from P0-P4 neurons (489 mIPSCs, $n=7$ ) and adult neurons (478 mIPSCs, $n=2$ ) with similarly low series resistances $(<8 \mathrm{M} \Omega)$. mIPSCs recorded from developing granule cells of the dentate gyrus, similar to the mIPSCs from adult dentate granule cells (Otis and Mody, 1992; Soltesz and Mody, 1995), could be satisfactorily fit with the sum of a single exponential rise and single exponential decay (i.e., the "SSE improvement" was not significant; see Materials and Methods) (Soltesz and Mody, 1995; Hollrigel et al., 1996) (Figs. 2A, 4). Analysis of the mIPSCs recorded from $\mathrm{P} 0-\mathrm{P} 4$ granule cells revealed that the $10-90 \%$ rise times (Fig. $2 A, C$ ) (or rise time constants, Fig. $3 A$ ) and the decay time constants (Fig. $2 D$ ) were significantly larger than the values obtained from adult neurons. Importantly, although the rise times and the decay time constants of the mIPSCs from P0-P4 neurons were significantly different from the adult, the mIPSC amplitudes were identical in $\mathrm{P} 0-\mathrm{P} 4$ and adult neurons (Fig. $2 A, B$ ).

Similar to $\mathrm{P} 0-\mathrm{P} 4$ pups, the $10-90 \%$ rise times and decay time constants of the mIPSCs of dentate granule cells from P5-P9 rats remained significantly slower compared with adult granule cells 

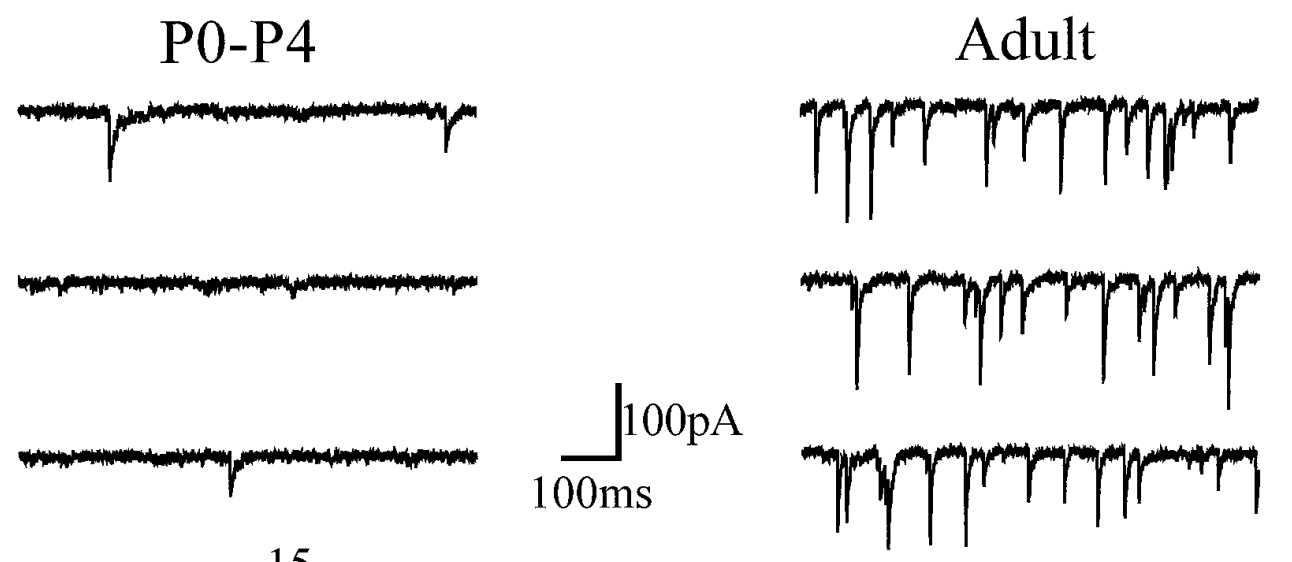

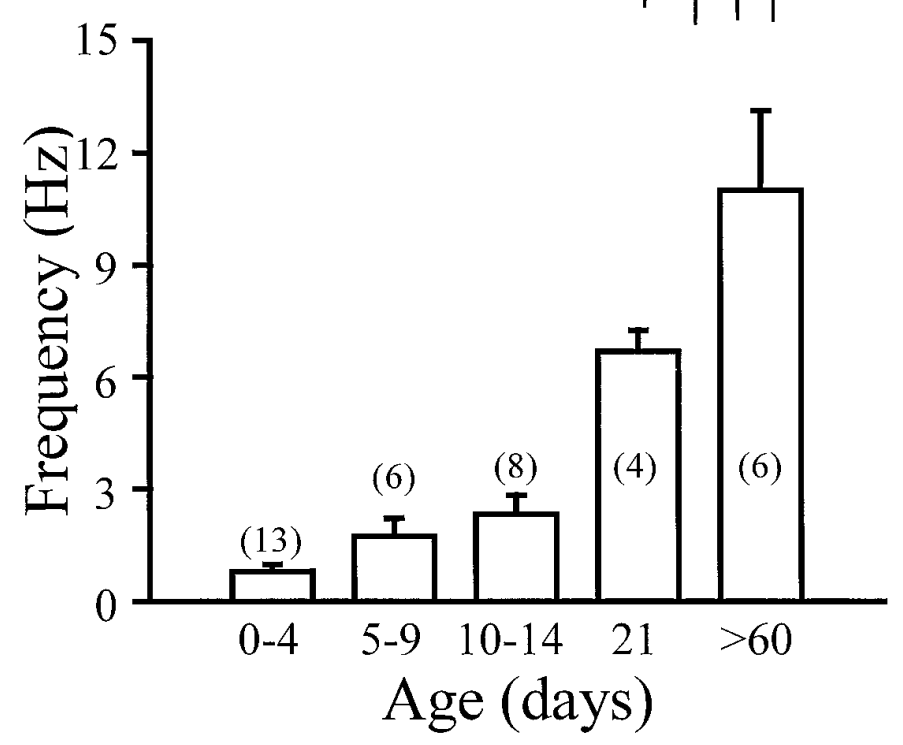

Figure 1. mIPSC frequency increases with age in dentate granule cells. Top traces are representative recordings of mIPSCs recorded in voltage-clamp at $-60 \mathrm{mV}$ with $\mathrm{CsCl}$-filled pipettes. The GABA-mediated $\mathrm{Cl}^{-}$currents reversed at $-0.5 \pm 2.1 \mathrm{mV}$ and were blocked by $20 \mu \mathrm{M}$ bicuculline (not shown). The bar graph is the summary of the frequency of mIPSCs as a function of age. The frequency continued to increase throughout the ages examined. $\mathrm{P} 0-\mathrm{P} 4$ : $0.8 \pm 0.2 \mathrm{~Hz}$; P5-P9: $1.7 \pm 0.5 \mathrm{~Hz} ; \mathrm{P} 10-$ P14: $2.3 \pm 0.5 \mathrm{~Hz} ; \mathrm{P} 21: 6.7 \pm 0.6 \mathrm{~Hz}$; adult: $11.0 \pm 2.1 \mathrm{~Hz}$. The number of cells is indicated in parentheses.
(Fig. $2 C, D)(n=3)$, with the amplitudes being similar (Fig. $2 B)$. The significance of these findings in P5-P9 rats is that basket cells are known to establish synapses on the somata of granule cells by P5 (Seress et al., 1989; Seress and Ribak, 1990). The presence of somatic synapses by P5-P8, the similar mIPSC amplitude, and the fact that there was no evidence of correlation in the rise time constant versus amplitude plots $\left(r^{2}=0.12\right)$ argue against the possibility that electrotonic filtering would underlie the observed kinetic differences (see Discussion). Indeed, the slower kinetics persisted in neurons recorded from animals younger than P15 (Fig. $3 A-C$ ). Figure $3, A$ and $B$, indicates that the rise time constants and decay time constants of the mIPSCs from animals younger than P15 were not different (rise time constant: P0-P4 = $0.41 \pm 0.05 \mathrm{msec}, n=13$; P10-P14 $=0.50 \pm 0.05 \mathrm{msec}, n=8$; decay time constant: $\mathrm{P} 0-\mathrm{P} 4=9.6 \pm 0.7 \mathrm{msec}, n=13$; P10-P14 $=$ $8.3 \pm 0.5 \mathrm{msec}, n=8)$. Both the rise time and decay time constants, however, decreased to the adult values by P21 (rise time constant: $0.20 \pm 0.01 \mathrm{msec}$; decay time constant: $5.2 \pm 0.4$ msec; $n=4)$. The lack of a change in the amplitude of the mIPSCs during development in dentate granule cells is shown in Figure $3 C$ $(\mathrm{P} 0-\mathrm{P} 4=74.0 \pm 3.8 \mathrm{pA}$; adult $=72.4 \pm 4.2 \mathrm{pA})$. It is interesting to note that the distributions of the rise and decay time constants and of the amplitude of the mIPSCs recorded from any single cell from all age groups showed the skewed distribution well described in the adult (e.g., Soltesz et al., 1995), i.e., there was no evidence of two distinct populations of mIPSCs in any given cell. The slower decay kinetics and the similar amplitude in the young granule cells resulted in a larger synaptic charge transfer of the synaptic $\mathrm{GABA}_{\mathrm{A}}$ receptors compared with adult (Fig. 3D) (P0$\mathrm{P} 4=242.3 \pm 22.2 \%$ of the adult; $\mathrm{P} 21=100.5 \pm 3.0 \%$ of the adult). These data indicate that for the first 2 weeks after birth, the kinetics of the GABA-mediated synaptic currents are slow and the synaptic charge transfer is relatively larger, and that during the third postnatal week the currents become faster and the charge transfer reaches its adult value by $\mathrm{P} 21$.

\section{The kinetics of IPSCs in granule cells correlates with the age of the animal and not with the maturational stage of the neuron}

In the experiments reported above, we noted that there was remarkably little variability between the mIPSC parameters in cells recorded from developing animals belonging to a particular age group (e.g., the SEM of the frequency in Fig. 1 is actually the largest in the adult group). Similarly, there was no significant difference between the kinetic properties of mIPSCs between the age groups $\mathrm{P} 0-\mathrm{P} 4, \mathrm{P} 5-\mathrm{P} 9$, and P10-P14. These observations were unexpected, because granule cells continue to be generated throughout the early postnatal period (and, albeit at a slower rate, even in the adult) (Kuhn et al., 1996), which means that granule cells in the early postnatal dentate gyrus can be at significantly different stages of maturation (see below). If the IPSC kinetics was determined by the neuronal maturational stage, we would have expected a large variability between the mIPSC characteristics of granule cells (i.e., some 
A

Figure 2. The kinetics of mIPSCs is slower in $\mathrm{P} 0-\mathrm{P} 4$ granule cells compared with adult granule cells, and kinetics of mIPSCs from P5-P9 neurons remains slower than that of adult neurons. $A$, Averages of 489 mIPSCs (P0P4) and 478 mIPSCs (adult) recorded at $-60 \mathrm{mV}$. Both the rise and decay are qualitatively slower than the adult current. The mIPSCs in the adult as well as in the young cells were fit by the sum of a single exponential rise and single exponential decay. The values for the equations were as follows: adult, $A=$ $-92.5 \mathrm{pA} ; \tau_{\mathrm{r}}=0.15 \mathrm{msec} ; \tau_{\mathrm{D}}=4.3$ msec; young: $A=-99.2 \mathrm{pA} ; \tau_{\mathrm{r}}=0.36$ msec; $\tau_{\mathrm{D}}=9.5$ msec. $B, C, D$, Cumulative probability plots of the amplitude, rise time (10-90\%), and single exponential decay time of the mIPSCs in $A$. The median amplitudes were $\mathrm{P} 0$ P4, 74.41 pA; P5-P9, 69.9 pA; adult: $76.37 \mathrm{pA}$. The median rise times were P0-P4, $0.91 \mathrm{msec}$; P5-P9, $1.03 \mathrm{msec}$; adult: $0.29 \mathrm{msec}$. The median decay time constants were $\mathrm{P} 0-\mathrm{P} 4,9.2 \mathrm{msec}$; P5-P9, 7.7 msec; adult, $4.5 \mathrm{msec}$. Significant differences of the distributions were found for the rise times and decay time constants for the $\mathrm{P} 0-\mathrm{P} 4 / \mathrm{P} 5-\mathrm{P} 9$ versus adult groups, whereas there was no significant difference between P0-P4 and P5-P9 (Kolmogorov-Smirnov test).

C

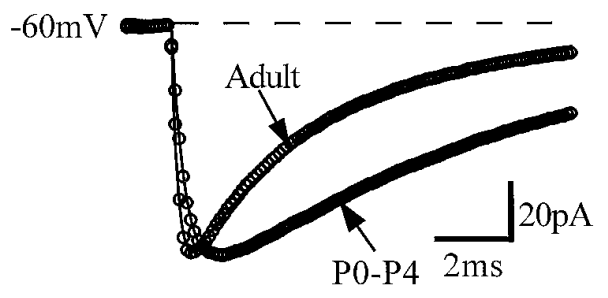

B
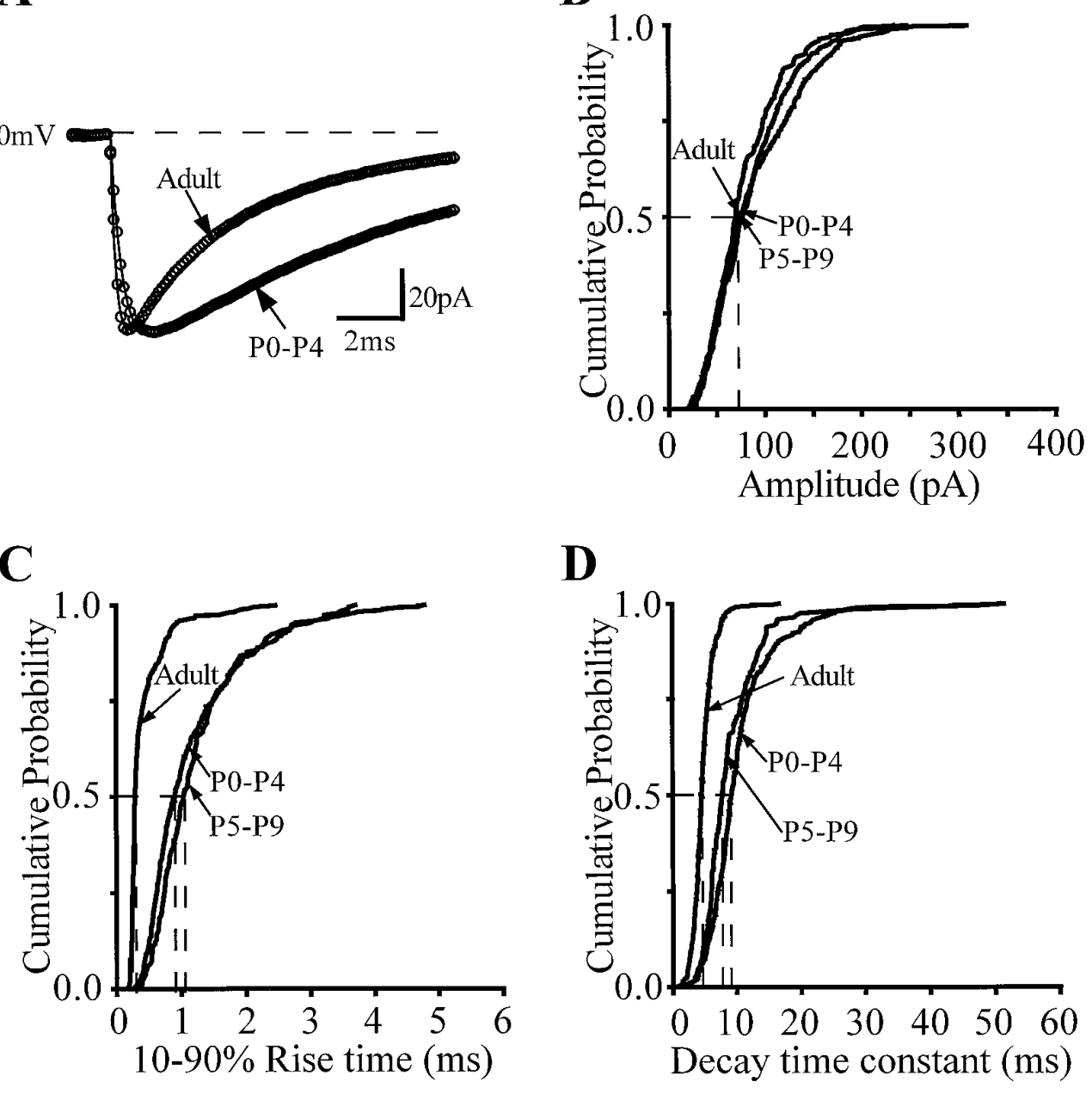

D

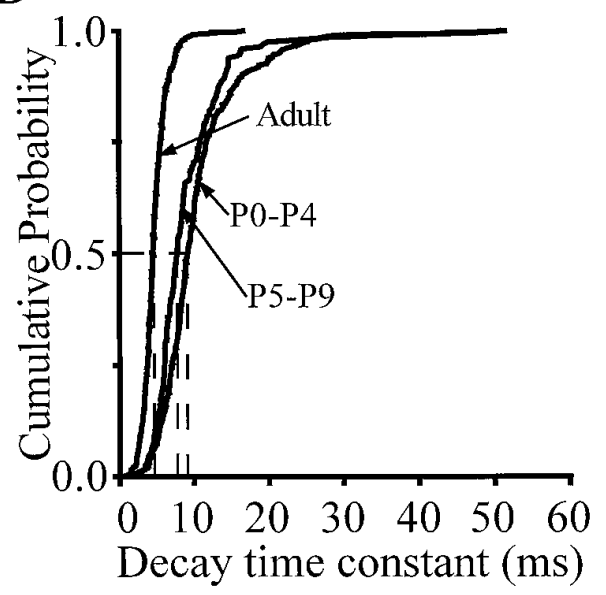

showing clearly immature-type kinetics, others adult-like kinetics). This is clearly not what was found, however, because before P14 virtually all granule cells had slow rise and decay kinetics, distinct from the kinetics observable in cells recorded after P21. To examine the relationship between the developmental stage of the cell and the properties of IPSCs, we performed experiments using biocytin injections and camera lucida reconstructions of cells recorded in the granule cell layer $(n=15)$. As illustrated in Figure 4, neurons at different maturational stages, evidenced by the differential complexity of the dendritic and axonal trees, clearly showed very similar kinetic parameters of IPSCs [note that all of the neurons were filled for $>20 \mathrm{~min}$, which is sufficient to completely fill the dendritic tree of even the larger, fully developed adult granule cells (Soltesz et al., 1995)]. Also, all of the processes of the immature-looking P 2 cell in Figure 4 ended within the slice and and not on the cut surface of the slice; similar morphologies of immature granule cells have been demonstrated previously (e.g., Cowan et al., 1980; Lubbers and Frotscher, 1988; Rihn and Claiborne, 1990; Liu et al., 1996). We classified the electrophysiologically recorded, morphologically identified granule cells in the following manner: simple cells, granule cells with 0-6 dendritic branch points; intermediate cells, granule cells with 7-13 dendritic branchpoints; and complex cells, granule cells with $>13$ dendritic branch points. The time constant data for these three groups were similar (simple cells: rise time constant, $0.43 \pm 0.06 \mathrm{msec}$; decay time constant, $10.6 \pm 0.8$ msec, $n=4$; intermediate cells: rise time constant, $0.53 \pm 0.09$ msec; decay time constant, $9.1 \pm 0.7 \mathrm{msec}, n=3$; complex cells: rise time constant, $0.47 \pm 0.12 \mathrm{msec}$; decay time constant, $10.0 \pm 1.8 \mathrm{msec}, n=3$ ). These findings indicate that it is the postnatal age of the animals (i.e., whether the animal is $<$ P15 or $>$ P21) that determines the kinetics of the mIPSCs and not the neuronal developmental stage. The importance of the third postnatal week in this respect may be related to the fact that the eyes of the rat pups open at approximately P14, and the animals start to move around and extensively explore the environment at the beginning of the third postnatal week, likely resulting in a relatively sudden increase in neuronal activity coming from the cortical areas to the dentate gyrus and the hippocampus.

A related issue concerns the identity of the recorded cells. Our experiments with biocytin filling and reconstructions showed that 12 of the 15 neurons filled in P0-P6 animals clearly met our strict criteria for granule cells: (1) the cell body was located within the granule cell layer; (2) the cell had an axon coursing through the hilus toward the CA3 region (i.e., along the mossy fiber pathway); and (3) the majority of the dendrites were oriented toward the molecular layer and did not curve back into the granule cell layer. Furthermore, the remaining three unclassified cells (which may include somewhat atypical granule cells as well as interneurons) showed no significant differences in their mIPSC kinetics with 

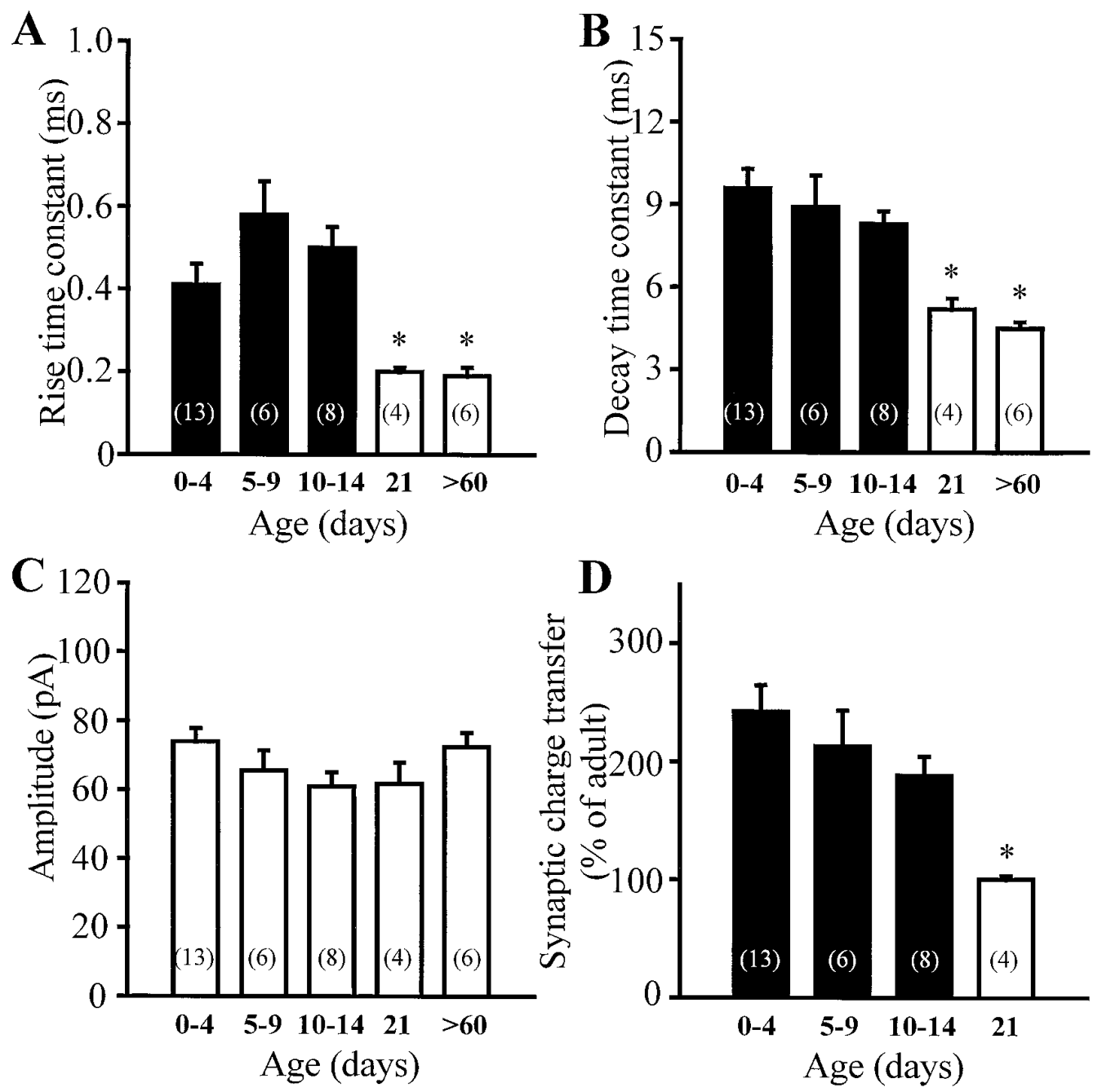

Figure 3. mIPSC kinetics is developmentally regulated. $A-C$, Summary data of the rise time constants, decay time constants, and amplitudes of the mIPSCs as a function of age. Bars of the same color are not statistically different ( $t$ test). Both the rise time constants and decay time constants significantly decreased at P21 and were not different from adult values. The amplitude of the mIPSCs did not change with age. $D$, Bar graph of the synaptic charge transfer (measured as the area under the best-fit curve describing the IPSCs) versus age. Consistent with the developmental change in kinetics, the synaptic charge transfer was larger in young neurons $(242.3 \pm 22.2 \%$ of the adult $)$ and decreased to adult values by P21 $(100.5 \pm 3.0 \%)$. Numbers in parentheses are the number of cells. respect to those neurons, which met our criteria for granule cells. Taken together, these results indicate that granule cells in the dentate gyrus from $<$ P15 show similarly slow kinetics, regardless of the maturational stage.

\section{Synaptic $\mathrm{GABA}_{\mathrm{A}}$ receptors in developing granule cells show differential sensitivity to subunit- specific modulators}

The subunit composition of $\mathrm{GABA}_{\mathrm{A}}$ receptors influences the main conductance state, kinetics, and sensitivity to modulators (Sigel et al., 1990; Verdoorn et al., 1990; Macdonald and Olsen, 1994). In adult granule cells, in situ hybridization and immunocytochemical studies have shown the expression of 10 different $\mathrm{GABA}_{\mathrm{A}}$ receptor subunits, including the $\alpha 1, \alpha 2, \alpha 4, \alpha 5, \beta 1, \beta 2$, $\beta 3, \gamma 1, \gamma 2$, and $\delta 1$ subtypes (Schoch et al., 1985; Richards et al., 1987; Houser et al., 1988; Benke et al., 1991; Zimprich et al., 1991; Laurie et al., 1992; Persohn et al., 1992; Turner et al., 1993; Gao and Fritschy, 1994; Gutierrez et al., 1994; Nusser et al., 1995). It is the $\alpha 1, \gamma 2$, and $\delta 1$ subunits that undergo the most prominent developmental changes in the dentate gyrus of postnatal rats (Killisch et al., 1991; Laurie et al., 1992; Poulter et al., 1992, 1993; Fritschy et al., 1994). Unlike in the hippocampus, $\alpha 5$ does not seem to change in the dentate gyrus (Killisch et al., 1991; Poulter et al., 1992), and these subunits have been shown to alter the time course of postsynaptic GABA signals, including the modulation of burst characteristics, activation, and desensitization rates (Ange- lotti and Macdonald, 1993; Saxena and Macdonald, 1994; Gingrich et al., 1995; Dominguez-Perrot et al., 1996). In the final series of experiments, we compared the sensitivity of the synaptic $\mathrm{GABA}_{\mathrm{A}}$ receptors in immature versus adult dentate granule cells with the presently available subunit-specific modulators zolpidem and zinc, whose modulatory actions are influenced by precisely those subunits that undergo developmental change in their levels of expression in the dentate gyrus, i.e., the $\alpha, \gamma 2$, and $\delta 1$ subunits (Draguhn et al., 1990; Pritchett and Seeburg, 1990; Puia et al., 1991; Davies et al., 1993; Mertens et al., 1993; Rovira and BenAri, 1993; Macdonald and Olsen, 1994; Saxena and Macdonald, 1994; White and Gurley, 1995; Kapur and Macdonald, 1996). Because of the very low mIPSC frequency in the immature cells, and the considerable time to achieve full potentiation of the decay time constant by zolpidem in these thick slices, these experiments were performed on slices incubated in the respective drug for 40-90 min [the percentage zolpidem potentiation of the decay time constant seen after switching from control to the drugcontaining solution in the same adult cells $(n=3)$ was not statistically different from that observed in cells obtained from slices incubated in zolpidem for 40-90 $\mathrm{min}$ (see below), i.e., once full potentiation is achieved, it remains stable; a similar approach has been used previously with propofol and thiopental, two drugs that also need a relatively long time for full effect in slices (Hollrigel et al., 1996)]. 
P2

Figure 4. $\quad \mathrm{GABA}_{\mathrm{A}}$ receptor-mediated synaptic currents of granule cells at different stages of development have similar kinetics. $A, B$, Two examples of granule cells recorded and stained with biocytin. The dashed lines indicate the borders of the granule cell layer. Note that both cells were located within the granule cell layer, each had an axon projecting through the hilus, and the majority of the dendrites were oriented toward the molecular layer. $C, D$, The averages of the IPSCs recorded from $A$ and $B$, respectively. Open circles are the raw data points; the solid line is the best-fit function describing the currents. Each cell, despite different stages of maturation, had similar IPSC kinetics. The values for the equations were (C) $A=-194.3 \mathrm{pA} ; \tau_{\mathrm{r}}=0.43 \mathrm{msec} ; \tau_{\mathrm{D}}$ $=11.1 \mathrm{msec} ;(D) A=-243.3 \mathrm{pA} ; \tau_{\mathrm{r}}=$ $0.37 \mathrm{msec} ; \tau_{\mathrm{D}}=13.5 \mathrm{msec}$. Note that the currents were accurately described by the sum of a single exponential rise and a single exponential decay.

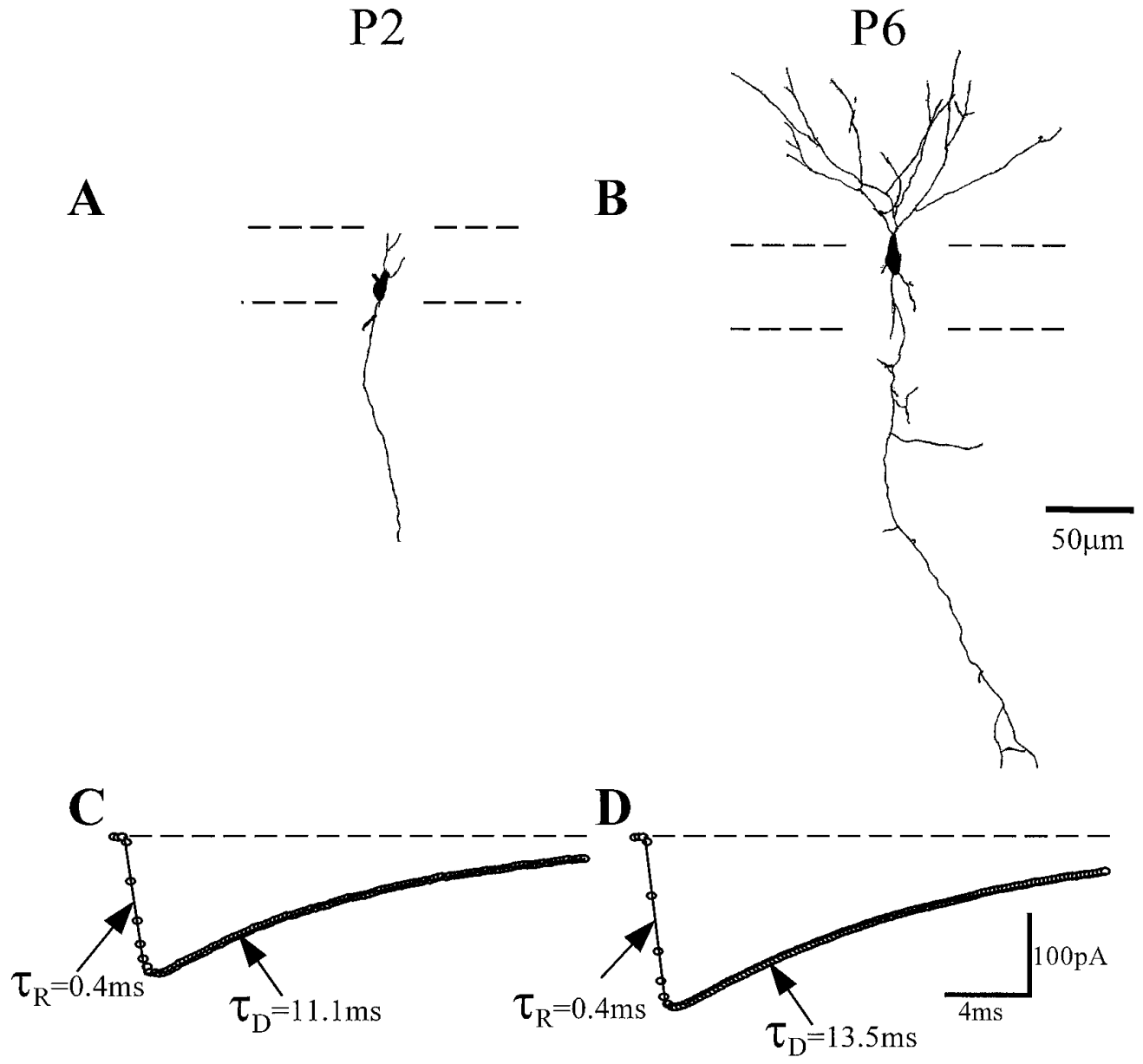

The benzodiazepine zolpidem has a higher affinity for $\mathrm{GABA}_{\mathrm{A}}$ receptors with $\alpha 1$ subunit compared with receptors with $\alpha 5$ subunit (Pritchett and Seeburg, 1990; Puia et al., 1991; Mertens et al., 1993), and it is known to prolong the decay of mIPSCs in adult dentate granule cells without affecting mIPSC amplitudes (Mody et al., 1994; Soltesz and Mody, 1994). Zolpidem at a concentration of $0.05 \mu \mathrm{M}$ did not change the decay time constant in either the young $(n=6)$ or adult $(n=4)$ IPSCs; however, the difference in potency was clearly evident at $0.5 \mu \mathrm{M}$ (Fig. 5$)$. In the adult $(n=4)$, $0.5 \mu \mathrm{M}$ zolpidem increased the decay time constant by $80.5 \pm$ $8.6 \%$, whereas in $\mathrm{P} 0-\mathrm{P} 4$ animals $(n=5)$ it increased the decay time constant by only $27.3 \pm 9.0 \%$. The difference in potentiation was reduced when a high concentration of zolpidem $(5.0 \mu \mathrm{M})$ was used (increase of decay time constant: P0-P4 $=82.0 \pm 30.3 \%$, $n=3$; adult $=97.2 \pm 5.1 \%, n=4)$.

Next, the effect of zinc (Westbrook and Mayer, 1987; Harrison and Gibbons, 1994; Smart et al., 1994; Buhl et al., 1996), whose blocking actions on the $\mathrm{GABA}_{\mathrm{A}}$ receptor is influenced by the $\alpha$, $\gamma 2$, and $\delta 1$ subunits (Draguhn et al., 1990; Macdonald and Olsen, 1994; White and Gurley, 1995), was tested in developing versus adult granule cells. Similar to previously published results (Buhl et al., 1996), zinc did not alter the mIPSCs in adult dentate granule cells (Fig. 6) $(n=4)$. By contrast, in granule cells from P0-P4 rats, zinc $(300 \mu \mathrm{M})$ significantly decreased the amplitude (control, $74.0 \pm 3.8 \mathrm{pA}$; zinc, $54.0 \pm 3.9 \mathrm{pA}$; a $27.0 \%$ decrease) and the decay time constant (control, $9.6 \pm 0.7 \mathrm{msec}$; zinc, $6.9 \pm 0.8 \mathrm{msec}$; a $28.1 \%$ decrease) of the mIPSCs $(n=7)$. Zinc did not change the rise time constant of the mIPSCs (control, $0.41 \pm 0.05 \mathrm{msec}$; zinc,

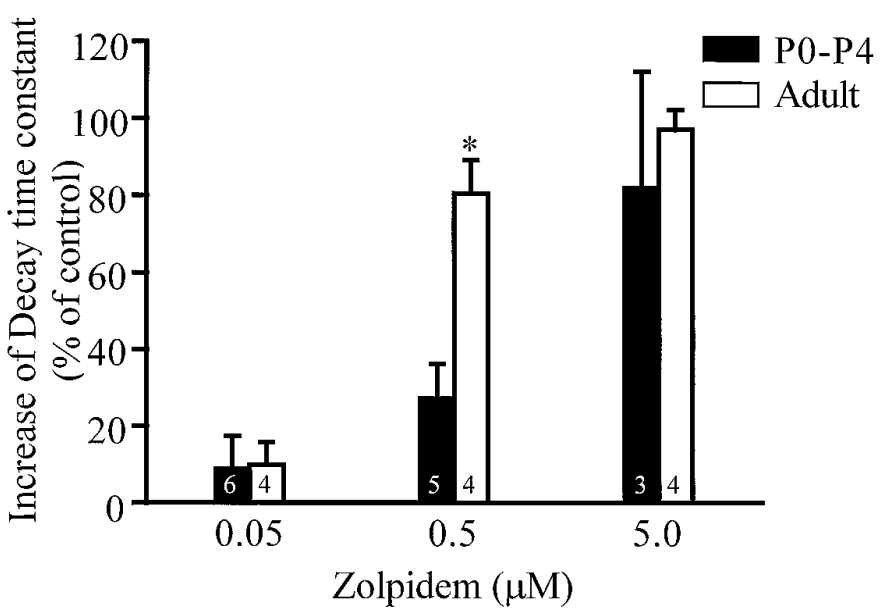

Figure 5. Synaptic $\mathrm{GABA}_{\mathrm{A}}$ receptors of young granule cells are less sensitive to modulation by zolpidem. In both the young and adult granule cells, $0.05 \mu \mathrm{M}$ zolpidem did not significantly increase the decay time constant of the IPSCs (P0-P4, $8.8 \pm 8.5 \%$ increase; adult, $9.8 \pm 5.9 \%$ increase); however, $0.5 \mu \mathrm{M}$ zolpidem increased the decay time constant of P0-P4 IPSCs by $27.3 \pm 9.0 \%$ and of adult IPSCs by $80.5 \pm 8.6 \%$. The difference in the relative increase caused by $0.5 \mu \mathrm{M}$ zolpidem was significant between the P0-P4 values and adult values. Zolpidem $(5.0 \mu \mathrm{M})$ increased P0-P4 IPSC decay times by $82.0 \pm 30.3 \%$ and adult IPSC decay times by $97.2 \pm 5.1 \%$. These effects were not significantly different ( $t$ test). Number of cells indicated within the bars. 


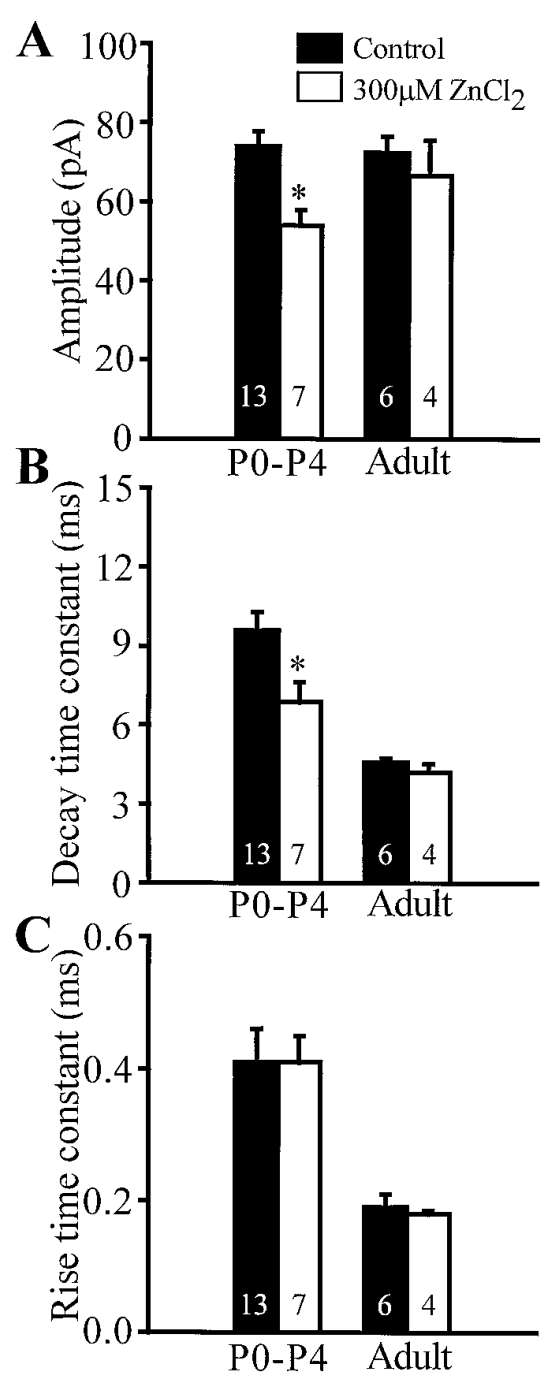

Figure 6. Zinc inhibits mIPSCs of young granule cells. $A-C$, Bar graphs comparing the effects of $\mathrm{ZnCl}_{2}(300 \mu \mathrm{M})$ on mIPSC amplitude, decay time constant, and rise time constant. Zinc significantly decreased the amplitude (control, $74.0 \pm 3.8 \mathrm{pA}$; zinc, $54.0 \pm 3.9 \mathrm{pA}$ ) and decay time constant (control, $9.6 \pm 0.7 \mathrm{msec}$; zinc, $6.9 \pm 0.8 \mathrm{msec}$ ) of P0-P4 mIPSCs. Zinc did not change the rise time constant of P0-P4 mIPSCs (control, $0.41 \pm 0.05$ msec; zinc, $0.41 \pm 0.04 \mathrm{msec}$ ). In addition, zinc did not change the parameters of adult mIPSCs: amplitude (control, $72.4 \pm 4.2 \mathrm{pA}$; zinc, $66.6 \pm 8.9 \mathrm{pA}$ ), decay time constant (control, $4.5 \pm 0.2 \mathrm{msec}$; zinc, $4.2 \pm$ $0.3 \mathrm{msec}$ ), rise time constant (control, $0.19 \pm 0.02 \mathrm{msec}$; zinc, $0.18 \pm 0.00$ $\mathrm{msec}$ ). Number of cells indicated within the bars.

$0.41 \pm 0.04 \mathrm{msec}$ ), indicating that the effect on the decay time constant was not attributable to an improved space-clamp resulting from the zinc-induced decrease in synaptic $\mathrm{GABA}_{\mathrm{A}}$ current amplitude. A lower concentration of zinc $(30 \mu \mathrm{M})$ also decreased both the amplitude (by $18.1 \pm 8.9 \% ; n=5$ ) and decay time constant (by $10.4 \pm 7.1 \% ; n=5$ ) in developing granule cells, albeit the difference with respect to control did not reach a statistically significant level. The smaller zolpidem potency and the larger effects of zinc on the mIPSCs in developing versus adult granule cells are likely to be related to the lower levels of expression of $\alpha 1, \gamma 2$, and $\delta 1$ subunits (Draguhn et al., 1990; Killisch et al., 1991; Poulter et al., 1992; Davies et al., 1993; Rovira and Ben-Ari, 1993; Fritschy et al., 1994; Macdonald and Olsen, 1994; White and Gurley, 1995). Thus, these pharmacological data indi- cate that age-dependent alterations take place in synaptic $\mathrm{GABA}_{\mathrm{A}}$ receptor properties in dentate granule cells.

\section{DISCUSSION}

The main findings of this study are that (1) functional GABAergic synaptic contacts are established on dentate granule cells immediately after birth; (2) the frequency of the mIPSCs increases with age; (3) the mIPSCs from immature granule cells as well as in the adult can be satisfactorily fitted with the sum of a single exponential rise and single exponential decay; (4) mIPSCs are slower in developing animals but are similar in amplitude compared with the adult, resulting in a developmental decrease in the synaptic charge transfer; (5) the kinetic properties of the mIPSCs depend on the postnatal age of the animal (i.e., whether the animal is younger or older than 3 weeks postnatal) and not on the maturational stage of the neuron; and (6) synaptic $\mathrm{GABA}_{\mathrm{A}}$ receptors in developing neurons are differentially sensitive to zolpidem and zinc, indicating subunit-dependent alterations in the functional properties of the $\mathrm{GABA}_{\mathrm{A}}$ channels during development.

\section{Early functional GABAergic synapses on immature granule cells}

The rate of granule cell generation reaches its peak between P5 and P7, at approximately 50,000 neurons per day (Schlessinger et al., 1975). Previous studies have shown that GABAergic neurons are born prenatally (Schlessinger et al., 1978; Amaral and Kurz, 1985; Lubbers et al., 1985), and by the end of the first postnatal week, they make synaptic contacts on granule cell dendrites as well as somata (Lubbers and Frotscher, 1988; Seress and Ribak, 1988, 1990). Although GABAergic responses have been shown to occur in developing hippocampal and cortical pyramidal cells (Mueller et al., 1984; Kriegstein et al., 1987; Janigro and Schwartzkroin, 1988; Ben-Ari et al., 1989; Gaiarsa et al., 1990; Blanton and Kriegstein, 1991; Luhmann and Prince, 1991; Zhang et al., 1991; Hosokawa et al., 1994; Fleidervish and Gutnick, 1995), the functional properties of the early $\mathrm{GABA}_{\mathrm{A}}$ receptormediated synaptic transmission in the late-developing dentate granule cells are not well understood. The data presented here demonstrate that the overwhelming majority of dentate granule cells of the early postnatal rat possess functionally active GABAergic synaptic inputs [interestingly, no glutamatergic synaptic events can be observed at this time in granule cells (our unpublished observations)], similar to CA1 and CA3 pyramidal cells (Ben-Ari et al., 1989; Hosokawa et al., 1994; Gaiarsa et al., 1995). Importantly, these first GABAergic synaptic inputs are likely to play significant roles in neuronal development (see below).

\section{Properties of the first GABAergic synaptic currents in dentate granule cells}

GABA is known to exert various effects on developing neurons (Hansen et al., 1984, 1988; LoTurco et al., 1995; Behar et al., 1996; Marty et al., 1996). Some of these effects can be observed when GABA is simply included in the incubation medium in cultures (e.g., Behar et al., 1996), i.e., presumably via the activation of mostly extrasynaptic receptors. Recent results, however, indicate that the synaptic release of GABA also plays an important role in neuronal maturation. Indeed, $\mathrm{GABA}_{\mathrm{A}}$ receptor-mediated synaptic potentials summate and cause enough depolarization to open voltage-gated $\mathrm{Ca}^{2+}$ channels and remove the $\mathrm{Mg}^{2+}$ block of NMDA channels, leading to increases in $\left[\mathrm{Ca}^{2+}\right]_{\mathrm{i}}$ (Ben-Ari et al., 1989; Cherubini et al., 1991; Yuste and Katz, 1991; Gaiarsa et al., 1995; Owens et al., 1996); GABA is depolarizing in both the adult 
and juvenile dentate granule cells (Staley and Mody, 1992; Soltesz and Mody, 1994; Liu et al., 1996). In the adult, summation of fast $\mathrm{GABA}_{\mathrm{A}}$ receptor-mediated postsynaptic currents, e.g., in hippocampal $40 \mathrm{~Hz}$ oscillations, requires highly precise synchronous release of GABA from presynaptic interneuronal axons (Buzsáki et al., 1983; Soltesz and Deschênes, 1993; Whittington et al., 1995). It seems reasonable to assume that the slower rising and slower decaying $\mathrm{GABA}_{\mathrm{A}}$ receptor-mediated synaptic signals in developing dentate granule cells may serve to provide a larger window of opportunity for the summation of postsynaptic GABA currents at a time when precision in the timing of action potentials may not have reached adult values (McCormick and Prince, 1987). Furthermore, the greater charge transfer is likely to lead to more effective depolarization and presumable $\mathrm{Ca}^{2+}$-channel activation.

Interestingly, several properties of the early GABAergic synapse seem to show marked differences between brain areas. For example, cerebellar granule cells show (1) a developmentally increasing activation of receptors by ambient GABA (evidenced by the larger bicuculline-sensitive baseline "noise" in mature cells), likely contributing to receptor desensitization; (2) a developmental increase in the contribution of the fast exponential to the spontaneous IPSC (sIPSC) decay (in these cells the sIPSC decay is described by double exponentials), related to receptor desensitization and a developmental increase in the expression of the $\alpha 6$ subunit; (3) a developmental decrease in the sIPSC amplitude; and (4) no change in the rise time constant (Tia et al., 1996). By contrast, in dentate granule cells (1) there is no significant change in the baseline noise, (2) the decay phase can be described by a single exponential in both adult and developing cells, (3) the mIPSC amplitude does not change, and (4) the mIPSC rise time constant decreases during development. These data suggest that the early GABAergic system may exhibit a staggering variety of phenotypes (Kraszewski and Grantyn, 1992; Oh et al., 1995), indicating that $\mathrm{GABA}_{\mathrm{A}}$ synaptic transmission may play developmental roles that are specific to various brain areas.

\section{Possible mechanisms underlying the slow mIPSC kinetics}

Recent anatomical studies indicate that transient GABAergic neurons of the inner molecular layer possess terminal-like varicosities in close juxtaposition to granule cells (Dupuy and Houser, 1996). The anatomical studies also suggested that granule cells may receive their first GABAergic contacts on their most proximal dendrites (Lubbers and Frotscher, 1988; Dupuy and Houser, 1996), followed by the innervation of the somatic region by basket cells (Seress et al., 1989); however, the unchanged mIPSC amplitude from P0 to adult argues against a major influence of electrotonic filtering on the mIPSC kinetics, because a more remote synaptic location (in the adult granule cells, mIPSCs are generated at synapses close to the soma) would severely affect the IPSC amplitudes (Soltesz et al., 1995). In fact, filtering affects the amplitude more than the rise time, because the amplitude decreases exponentially whereas the rise time increases only linearly as the synapse is moved from the soma toward the distal dendrites (Soltesz et al., 1995). Furthermore, P5-P14 cells also showed slower kinetics, and at these later postnatal dates GABAergic synapses have been demonstrated on granule cell somata (Seress and Ribak, 1988; Seress et al., 1989). A related issue is that in the early postnatal dentate, GABAergic synaptic junctions are difficult to identify morphologically (Dupuy and Houser, 1996), raising the possibility of a developmental difference in synaptic cleft distance; however, a larger cleft distance would not only slow the kinetics, but would also decrease the mIPSC amplitude (Evers et al., 1989). Similarly, because GABA uptake blockers do not prolong the mIPSC decay in granule cells (Otis and Mody, 1992; Thompson and Gähwiler, 1992), an increased uptake in adult cells cannot explain the speeding up of the GABA currents during development (also, a weaker uptake in immature cells is unlikely to underlie the slower rise kinetics). Differential $\mathrm{GABA}_{\mathrm{A}}$ receptor properties resulting from developmental changes in subunit composition (Mathews et al., 1994; Oh et al., 1995; Gibbs et al., 1996), indicated by the zolpidem and zinc data, are likely to be a major factor in determining the slow mIPSC kinetics. Because the $\alpha 1$, $\gamma 2$, and $\delta 1$ subunits significantly increase their expression levels around the second and third postnatal weeks in the dentate (Killisch et al., 1991; Poulter et al., 1992; Fritschy et al., 1994) and are known to influence the time course of $\mathrm{GABA}_{\mathrm{A}}$ signals in expression systems (Angelotti and Macdonald, 1993; Saxena and Macdonald, 1994; Gingrich et al., 1995; Dominguez-Perrot et al., 1996), it seems likely that the developmentally regulated expression of all of these three subunits contributes to the observed kinetic and pharmacological changes in $\mathrm{GABA}_{\mathrm{A}}$ IPSCs in dentate granule cells. An exciting additional possibility, to be explored in future studies, is that age- and subunit-dependent modification of the existing and the newly synthesized receptor subunits may also contribute to the developmental changes of mIPSC kinetics.

\section{Temporal profile of the developmental changes in mIPSC kinetics}

Our results show that statistically significant change in the mIPSC kinetics occurred only after the end of the second postnatal week. In addition, before the third week there was no difference between the mIPSC kinetics in granule cells, which on the basis of their dendritic morphology seemed to be at different stages of neuronal development. These findings indicate that the changes in kinetics do not occur at a predetermined time after the last mitosis of the cell. Rather, the kinetic changes in mIPSCs around the third postnatal week are likely to be triggered by signals that affect most granule cells at approximately the same time, regardless of their developmental stage. It will be of great interest in future studies to identify the nature of the signals that determine the developmental changes in GABAergic synaptic signaling.

\section{REFERENCES}

Angelotti TP, Macdonald RL (1993) Assembly of GABA A $_{\text {receptor sub- }}$ units: $\alpha 1 \beta 1$ and $\alpha 1 \beta 1 \gamma 2 \mathrm{~S}$ subunits produce unique ion channels with dissimilar single-channel properties. J Neurosci 13:1429-1440.

Amaral DG, Kurz J (1985) The time of origin of cells demonstrating glutamic acid decarboxylase-like immunoreactivity in the hippocampal formation of the rat. Neurosci Lett 59:33-39.

Bayer SA (1980) Development of the hippocampal region in the rat. I. Neurogenesis examined with $3 \mathrm{H}$-thymidine autoradiography. J Comp Neurol 190:87-114.

Behar TN, Li Y, Tran HT, Ma W, Dunlap V, Scott C, Barker JL (1996) GABA stimulates chemotaxis and chemokinesis of embryonic cortical neurons via calcium-dependent mechanisms. J Neurosci 16:1808-1818.

Ben-Ari Y, Cherubini E, Corradetti R, Gaiarsa J (1989) Giant synaptic potentials in immature rat CA3 hippocampal neurones. J Physiol (Lond) 416:303-325.

Benke D, Mertens S, Trzeciak A, Gillessen D, Mohler H (1991) Identification and immunohistochemical mapping of $\mathrm{GABA}_{\mathrm{A}}$ receptor subtypes containing the delta-subunit in rat brain. FEBS Lett 283:145-149.

Blanton MG, Kriegstein AR (1991) Spontaneous action potential activity and synaptic currents in the embryonic turtle cerebral cortex. J Neurosci 11:3907-3923.

Blanton MG, LoTurco JJ, Kriegstein AR (1989) Whole cell recording from neurons in slices of reptilian and mammalian cerebral cortex. J Neurosci Methods 30:203-210.

Buhl EH, Otis TS, Mody I (1996) Zinc-induced collapse of augmented 
inhibition by GABA in a temporal lobe epilepsy model. Science 271:369-373.

Buzsáki G, Leung LW, Vanderwolf CH (1983) Cellular bases of hippocampal EEG in the behaving rat. Brain Res 287:139-171.

Cherubini E, Gaiarsa JL, Ben-Ari Y (1991) GABA: an excitatory transmitter in early postnatal life. Trends Neurosci 14:515-519.

Claiborne BJ, Amaral DG, Cowan WM (1986) A light and electron microscopic analysis of the mossy fibers of the rat dentate gyrus. J Comp Neurol 246:435-458.

Cobb SR, Buhl EH, Halasy K, Paulsen O, Somogyi P (1995) Synchronization of neuronal activity in hippocampus by individual GABAergic interneurons. Nature 378:75-78.

Cowan WM, Stanfield BB, Kishi K (1980) The development of the dentate gyrus. Curr Top Dev Biol 15:103-157.

Davies MF, Maguire PA, Loew GH (1993) Zinc selectively inhibits flux through benzodiazepine-insensitive $\gamma$-aminobutyric acid chloride channels in cortical and cerebellar microsacs. Mol Pharmacol 44:876-881.

Dominguez-Perrot C, Feltz P, Poulter MO (1996) Recombinant GABA receptor desensitization: the role of the $\gamma 2$ subunit and its physiological significance. J Physiol (Lond) 497:145-159.

Draguhn A, Verdorn TA, Ewert M, Seeburg PH, Sakmann B (1990) Functional and molecular distinction between recombinant rat $\mathrm{GABA}_{\mathrm{A}}$ receptor subtypes by $\mathrm{Zn}^{2+}$. Neuron 5:781-788.

Dupuy ST, Houser CR (1996) Prominent expression of two forms of glutamate decarboxylase in the embryonic and early postnatal rat hippocampal formation. J Neurosci 16:6919-6932.

Evers J, Laser M, Sun Y, Xie Z, Poo M-M (1989) Studies of nervemuscle interactions in Xenopus cell culture: analysis of early synaptic contacts. J Neurosci 9:1523-1539.

Fleidervish IA, Gutnick MJ (1995) Paired-pulse facilitation of IPSCs in slices of immature and mature mouse somatosensory neocortex. J Neurophysiol 73:2591-2595.

Freund TF, Buzsáki G (1996) Interneurons of the hippocampus. Hippocampus 6:345-470.

Fritschy JM, Paysan J, Enna A, Mohler H (1994) Switch in the expression of rat $\mathrm{GABA}_{\mathrm{A}}$-receptor subtypes during postnatal development: an immunohistochemical study. J Neurosci 14:5302-5324.

Fukuda A, Mody I, Prince DA (1993) Differential ontogenesis of presynaptic and postsynaptic $\mathrm{GABA}_{\mathrm{B}}$ inhibition in rat somatosensory cortex. J Neurophysiol 70:448-452.

Gaiarsa JL, Corradetti R, Ben-Ari Y, Cherubini E (1990) GABA mediated synaptic events in neonatal rat CA3 pyramidal neurons in vitro: modulation by NMDA and non-NMDA receptors. Adv Exp Med Biol 268:151-159.

Gaiarsa JL, McLean H, Congar P, Leinekugel X, Khazipov R, Tseeb V, Ben-Ari Y (1995) Postnatal maturation of gamma-aminobutyric acidA and B-mediated inhibition in the CA3 hippocampal region of the rat. J Neurobiol 26:339-349.

Gao B, Fritschy JM (1994) Selective allocation of $\mathrm{GABA}_{\mathrm{A}}$ receptors containing the alpha 1 subunit to neurochemically distinct subpopulations of rat hippocampal interneurons. Eur J Neurosci 6:837-853.

Gibbs JW, Schroder GB, Coulter DA (1996) GABA $_{\mathrm{A}}$ receptor function in developing rat thalamic reticular neurons: whole cell recordings of GABA-mediated currents and modulation by clonazepam. J Neurophysiol 76:2568-2579.

Gingrich KJ, Roberts WA, Kass RS (1995) Dependence of the GABA receptor gating kinetics on the $\alpha$-subunit isoform: implications for structure-function relations and synaptic transmission. J Physiol (Lond) 489:529-543.

Gutierrez A, Kahn ZU, De Blas A (1994) Immunocytochemical localization of gamma 2 short and gamma 2 long subunits of the $\mathrm{GABA}_{\mathrm{A}}$ receptor in the rat brain. J Neurosci 14:7168-7179.

Halasy K, Somogyi P (1993) Subdivisions in the multiple GABAergic innervation of granule cells in the dentate gyrus of the rat hippocampus. Eur J Neurosci 5:411-429.

Han ZS, Buhl EH, Lorinczi Z, Somogyi P (1993) A high degree of spatial selectivity in the axonal and dendritic domains of physiologically identified local-circuit neurons in the dentate gyrus of the rat hippocampus. Eur J Neurosci 5:395-410.

Hansen GH, Meier E, Schousboe A (1984) GABA influences the ultrastructure composition of cerebellar granule cells during development in culture. Int J Dev Neurosci 2:247-257.

Hansen GH, Belhage B, Schousboe A, Meier E (1988) Gammaaminobutyric acid agonist-induced alterations in the ultrastructure of cultured cerebellar granule cells is restricted to early development. J Neurochem 51:243-245.

Harrison NL, Gibbons SJ (1994) $\mathrm{Zn}^{2+}$ : an endogenous modulator of ligandand voltage-gated ion channels. Neuropharmacology 33:935-952.

Hollrigel GS, Toth K, Soltesz I (1996) Neuroprotection by propofol in acute mechanical injury: role of GABAergic inhibition. J Neurophysiol 76:2412-2422.

Hosokawa Y, Sciancalepore M, Stratta F, Martina M, Cherubini E (1994) Developmental changes in spontaneous $\mathrm{GABA}_{\mathrm{A}}$-mediated synaptic events in rat hippocampal CA3 neurons. Eur J Neurosci 6:805-813.

Houser CR, Olsen RW, Richards JG, Mohler H (1988) Immunohistochemical localization of benzodiazepine/ $\mathrm{GABA}_{\mathrm{A}}$ receptors in the human hippocampal formation. J Neurosci 8:1370-1383.

Janigro D, Schwartzkroin PA (1988) Effects of GABA and baclofen on pyramidal cells in the developing rabbit hippocampus: an "in vitro" study. Brain Res 469:171-184.

Kapur J, Macdonald RL (1996) Pharmacological properties of $\gamma$-aminobutyric acid $_{\mathrm{A}}$ receptors from acutely dissociated rat dentate granule cells. Mol Pharmacol 50:458-466.

Killisch I, Dotti CG, Laurie DJ, Luddens H, Seeburg PH (1991) Expression patterns of $\mathrm{GABA}_{\mathrm{A}}$ receptor subtypes in developing hippocampal neurons. Neuron 7:927-936.

Kraszewski K, Grantyn R (1992) Development of GABAergic connections in vitro: increasing efficacy of synaptic transmission is not accompanied by changes in miniature currents. J Neurobiol 23:766-781.

Kriegstein AR, Suppes T, Prince DA (1987) Cellular and synaptic physiology and epileptogenesis of developing rat neocortical neurons in vitro. Brain Res 431:161-171.

Kuhn HG, Dickinson-Anson H, Gage FH (1996) Neurogenesis in the dentate gyrus of the adult rat: age-related decrease of neuronal progenitor proliferation. J Neurosci 16:2027-2033.

Laurie DJ, Wisden W, Seeburg PH (1992) The distribution of thirteen $\mathrm{GABA}_{\mathrm{A}}$ receptor subunit mRNAs in the rat brain. III. Embryonic and postnatal development. J Neurosci 12:4151-4172.

Liu Y-B, Lio PA, Pasternak JF, Trommer BL (1996) Developmental changes in membrane properties and postsynaptic currents in rat dentate gyrus. J Neurophysiol 76:1074-1088.

LoTurco JJ, Owens DF, Heath MJS, Davis MBE, Kriegstein AR (1995) GABA and glutamate depolarize cortical progenitor cells and inhibit DNA synthesis. Neuron 15:1287-1298.

Lubbers K, Frotscher M (1988) Differentiation of granule cells in relation to GABAergic neurons in the rat fascia dentata. Anat Embryol 178:119-127.

Lubbers K, Wolff JR, Frotscher M (1985) Neurogenesis of GABAergic neurons in the rat dentate gyrus: a combined autoradiographic and immunocytochemical study. Neurosci Lett 62:317-322.

Luhmann HJ, Prince DA (1991) Postnatal maturation of the GABAergic system in rat neocortex. J Neurophysiol 65:247-263.

Macdonald RL, Olsen RW (1994) GABA $_{\mathrm{A}}$ receptor channels. Annu Rev Neurosci 17:569-602.

Marty S, Berninger B, Carroll P, Thoenen H (1996) GABAergic stimulation regulates the phenotype of hippocampal interneurons through the regulation of brain-derived neurotrophic factor. Neuron 16:565-570.

Mathews GC, Bolos-Sy AM, Holland KD, Isenberg KE, Covey DF, Ferrendelli JA, Rothman SM (1994) Developmental alteration in $\mathrm{GABA}_{\mathrm{A}}$ receptor structure and physiological properties in cultured cerebellar granule neurons. Neuron 13:149-158.

McCormick DA, Prince DA (1987) Post-natal development of electrophysiological properties of rat cerebral cortical pyramidal neurones. J Physiol (Lond) 393:743-762.

Mertens S, Benke D, Mohler H (1993) GABA $_{A}$ receptor populations with novel subunit combinations and drug binding profiles identified in brain by alpha 5 - and delta-subunit-specific immunopurification. J Biol Chem 268:5965-5973.

Miles R, Toth K, Gulyas AI, Hajos N, Freund TF (1996) Differences between somatic and dendritic inhibition in the hippocampus. Neuron 16:815-823.

Mody I, DeKoninck Y, Otis TS, Soltesz I (1994) Bridging the cleft at GABA synapses in the brain. Trends Neurosci 17:517-525.

Mueller AL, Taube JS, Schwartzkroin PA (1984) Development of hyperpolarizing inhibitory postsynaptic potentials and hyperpolarizing response to gamma-aminobutyric acid in rabbit hippocampus studied in vitro. J Neurosci 4:860-867.

Nusser Z, Roberts JD, Baude A, Richards JG, Sieghart W, Somogyi P 
(1995) Immunocytochemical localization of the alpha 1 and beta $2 / 3$ subunits of the $\mathrm{GABA}_{\mathrm{A}}$ receptor in relation to specific GABAergic synapses in the dentate gyrus. Eur J Neurosci 7:630-646.

Oh K, Lee C, Gibbs JW, Coulter DA (1995) Postnatal development of $\mathrm{GABA}_{\mathrm{A}}$ receptor function in somatosensory thalamus and cortex: whole-cell voltage-clamp recordings in acutely isolated rat neurons. J Neurosci 15:1341-1351.

Otis TS, Mody I (1992) Modulation of decay kinetics and frequency of $\mathrm{GABA}_{\mathrm{A}}$ receptor-mediated spontaneous inhibitory postsynaptic currents in hippocampal neurons. Neuroscience 49:13-32.

Owens DF, Boyce LH, Davis MBE, Kriegstein AR (1996) Excitatory GABA responses in embryonic and neonatal cortical slices demonstrated by gramicidin perforated-patch recordings and calcium imaging. J Neurosci 16:6414-6423.

Persohn E, Malherbe P, Richards JG (1992) Comparative molecular neuroanatomy of cloned $\mathrm{GABA}_{\mathrm{A}}$ receptor subunits in the rat CNS. J Comp Neurol 326:193-216.

Poulter MO, Barker JL, O'Carroll AM, Lolait SJ, Mahan LC (1992) Differential and transient expression of $\mathrm{GABA}_{\mathrm{A}}$ receptor alpha-subunit mRNAs in the developing rat CNS. J Neurosci 12:2888-2900.

Poulter MO, Barker JL, O'Carroll AM, Lolait SJ, Mahan LC (1993) Co-existent expression of $\mathrm{GABA}_{\mathrm{A}}$ receptor beta 2, beta 3 and gamma 2 subunit messenger RNAs during embryogenesis and early postnatal development of the rat central nervous system. Neuroscience 53:1019-1033.

Pritchett DB, Seeburg PH (1990) Gamma-aminobutyric acidA receptor alpha 5-subunit creates novel type II benzodiazepine receptor pharmacology. J Neurochem 54:1802-1804.

Puia G, Vicini S, Seeburg PH, Costa E (1991) Influence of recombinant $\gamma$-aminobutyric acid- ${ }_{\mathrm{A}}$ receptor subunit composition on the action of allosteric modulators of $\gamma$-aminobutyric acid-gated $\mathrm{Cl}^{-}$currents. Mol Neuropharmacol 39:691-696.

Richards JG, Schoch P, Haring P, Takacs B, Mohler H (1987) Resolving $\mathrm{GABA}_{\mathrm{A}}$ /benzodiazepine receptors: cellular and subcellular localization in the CNS with monoclonal antibodies. J Neurosci 7:1866-1886.

Rihn LL, Claiborne BJ (1990) Dendritic growth and regression in rat dentate granule cells during late postnatal development. Dev Brain Res $54: 115-124$.

Rohrbough J, Spitzer NC (1996) Regulation of intracellular $\mathrm{Cl}^{-}$levels by $\mathrm{Na}(+)$-dependent $\mathrm{Cl}^{-}$cotransport distinguishes depolarizing from hyperpolarizing $\mathrm{GABA}_{\mathrm{A}}$ receptor-mediated responses in spinal neurons. J Neurosci 16:82-91.

Rovira C, Ben-Ari Y (1993) Developmental study of benzodiazepine effects on monosynaptic $\mathrm{GABA}_{\mathrm{A}}$-mediated IPSPs of rat hippocampal neurons. J Neurophysiol 70:1076-1085.

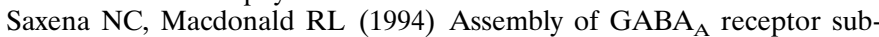
units: role of the delta subunit. J Neurosci 14:7077-7086.

Schlessinger AR, Cowan WM, Gottlieb DI (1975) An autoradiographic study of the time of origin and the pattern of granule cell migration in the dentate gyrus of the rat. J Comp Neurol 159:149-175.

Schlessinger AR, Cowan WM, Swanson LW (1978) The time of origin of neurons in Ammon's horn and the associated retrohippocampal fields. Anat Embryol 154:153-173.

Schoch P, Richards JG, Haring P, Takacs B, Stahli C, Staehelin T, Haefely W, Mohler H (1985) Co-localization of GABA receptors and benzodiazepine receptors in the brain shown by monoclonal antibodies. Nature 314:168-171.

Seress L, Ribak CE (1988) The development of GABAergic neurons in the rat hippocampal formation: an immunocytochemical study. Dev Brain Res 44:197-209.

Seress L, Ribak CE (1990) The synaptic connections of basket cell axons in the developing rat hippocampal formation. Exp Brain Res 81:500-508.
Seress L, Frotscher M, Ribak CE (1989) Local circuit neurons in both the dentate gyrus and Ammon's horn establish synaptic connections with principal neurons in five day old rats: a morphological basis for inhibition in early development. Exp Brain Res 78:1-9.

Sigel E, Baur R, Trube G, Mohler H, Malherbe P (1990) The effect of subunit composition of rat brain $\mathrm{GABA}_{\mathrm{A}}$ receptors on channel function. Neuron 5:703-711.

Smart TG, Xie X, Krishek BJ (1994) Modulation of inhibitory and excitatory amino acid receptor ion channels by zinc. Prog Neurobiol 42:393-341.

Soltesz I, Deschênes M (1993) Low- and high-frequency membrane potential oscillations during theta activity in CA1 and CA3 pyramidal neurons of the rat hippocampus under ketamine-xylazine anesthesia. J Neurophysiol 70:97-116.

Soltesz I, Mody I (1994) Patch-clamp recordings reveal powerful GABAergic inhibition in dentate hilar neurons. J Neurosci 14:2365-2376.

Soltesz I, Mody I (1995) $\mathrm{Ca}^{2+}$-dependent plasticity of miniature inhibitory postsynaptic currents after amputation of dendrites in central neurons. J Neurophysiol 73:1763-1773.

Soltesz I, Smetters DK, Mody I (1995) Tonic inhibition originates from synapses close to the soma. Neuron 14:1273-1283.

Soriano E, Cobas A, Fairen A (1989) Neurogenesis of glutamic acid decarboxylase immunoreactive cells in the hippocampus of the mouse. II. Area dentata. J Comp Neurol 281:603-611.

Staley KJ, Mody I (1992) Shunting of excitatory input to dentate gyrus granule cells by a depolarizing $\mathrm{GABA}_{\mathrm{A}}$ receptor-mediated postsynaptic conductance. J Neurophysiol 68:197-212.

Staley KJ, Otis TS, Mody I (1992) Membrane properties of dentate gyrus granule cells: comparison of sharp microelectrode and whole-cell recordings. J Neurophysiol 67:1346-1358.

Tia S, Wang JF, Kotchabhakdi N, Vicini S (1996) Developmental changes of inhibitory synaptic currents in cerebellar granule neurons: role of $\mathrm{GABA}_{\mathrm{A}}$ receptor $\alpha 6$ subunit. J Neurosci 16:3630-3640.

Thompson SM, Gahwiler BH (1992) Effects of the GABA uptake inhibitor tiagabine on inhibitory synaptic potentials in rat hippocampal slice cultures. J Neurophysiol 67:1698-1701.

Turner JD, Bodewitz G, Thompson CL, Stephenson FA (1993) Immunohistochemical mapping of gamma-aminobutyric acid type-A receptor alpha subunits in rat central nervous system. Psychopharmacol Ser 11:29-49.

Verdoorn TA, Draguhn A, Ymer S, Seeburg PH, Sakmann B (1990) Functional properties of recombinant rat $\mathrm{GABA}_{\mathrm{A}}$ receptors depend upon subunit composition. Neuron 4:919-928.

Westbrook GL, Mayer ML (1987) Micromolar concentrations of $\mathrm{Zn}^{2+}$ antagonize NMDA and GABA responses of hippocampal neurons. Nature 328:640-643.

White G, Gurley DA (1995) A receptor currents. NeuroReport 6:461-464.

Whittington MA, Traub RD, Jefferys JG (1995) Synchronized oscillations in interneuron networks driven by metabotropic glutamate receptor activation. Nature 373:612-615.

Yuste R, Katz LC (1991) Control of postsynaptic $\mathrm{Ca}^{2+}$ influx in developing neocortex by excitatory and inhibitory neurotransmitters. Neuron 6:333-344.

Zhang L, Spigelman I, Carlen PL (1991) Development of GABAmediated, chloride-dependent inhibition in CA1 pyramidal neurones of immature rat hippocampal slices. J Physiol (Lond) 444:25-49.

Zimprich F, Zezula J, Sieghart W, Lassmann H (1991) Immunohistochemical localization of the alpha 1 , alpha 2 and alpha 3 subunit of the $\mathrm{GABA}_{\mathrm{A}}$ receptor in the rat brain. Neurosci Lett 127:125-128. 